\title{
Evidence-based economic analysis demonstrates that ecosystem service benefits of water hyacinth management greatly exceed research and control costs
}

\author{
Lisa A Wainger ${ }^{\text {Corresp., }}{ }^{1}$, Nathan E Harms ${ }^{2}$, Cedric Magen ${ }^{1}$, Dong Liang ${ }^{1}$, Genevieve M Nesslage ${ }^{1}$, Anna M \\ McMurray $^{1}$, Al F Cofrancesco ${ }^{2}$ \\ ${ }^{1}$ Chesapeake Biological Laboratory, University of Maryland Center for Environmental Science, Solomons, MD, United States \\ Engineer Research and Development Center, US Army Corps of Engineers, Vicksburg, MS, United States \\ Corresponding Author: Lisa A Wainger \\ Email address: wainger@umces.edu
}

Invasive species management can be a victim of its own success when decades of effective control cause memories of past harm to fade and raise questions of whether programs should continue. Economic analysis can be used to assess the efficiency of investing in invasive species control by comparing ecosystem service benefits to program costs, but only if appropriate data exist. We used a case study of water hyacinth (Eichhornia crassipes (Mart.) Solms), a nuisance floating aquatic plant, in Louisiana to demonstrate how comprehensive record-keeping supports economic analysis. Using long-term data sets, we developed empirical and spatio-temporal simulation models of intermediate complexity to project invasive species growth for control and no-control scenarios.

For Louisiana, we estimated that peak plant cover would be $76 \%$ higher without the substantial growth rate suppression (84\% reduction) that appeared due primarily to biological control agents. Our economic analysis revealed that combined biological and herbicide control programs, monitored over an unusually long time period (1975-2013), generated a benefit-cost ratio of about 34:1 derived from the relatively modest costs of $\$ 124$ million ( $\$ 2013$ ) compared to the $\$ 4.2$ billion ( $\$ 2013$ ) in benefits to anglers, waterfowl hunters, boating-dependent businesses, and water treatment facilities over the 38-year analysis period. This work adds to the literature by 1) providing evidence of the effectiveness of water hyacinth biological control; 2) demonstrating use of parsimonious spatio-temporal models to estimate benefits of invasive species control; and 3) incorporating activity substitution into economic benefit transfer to avoid overstating benefits. Our study suggests that robust and cost-effective economic analysis is enabled by good record keeping and generalizable models that can demonstrate management effectiveness and promote social efficiency of invasive species control. 


\section{Evidence-based economic analysis demonstrates that ecosystem service}

2 benefits of water hyacinth management greatly exceed research and control

3 costs

4 L.A. Wainger ${ }^{1}$, N.E. Harms ${ }^{2}$, C. Magen ${ }^{1}$, D. Liang ${ }^{1}$, G.M. Nesslage ${ }^{1}$, A. McMurray ${ }^{1 *}$, A.F.

5 Cofrancesco $^{2}$

$6 \quad{ }^{1}$ University of Maryland Center for Environmental Science, Chesapeake Biological Laboratory,

7 Solomons, MD, United States

$8{ }^{2}$ US Army Corps of Engineers, Engineer Research and Development Center, Vicksburg, MS,

9 United States

$10 *$ currently at Winrock International, Arlington, VA, United States

11 Corresponding Author: Lisa Wainger, wainger@umces.edu

12 


\section{Abstract}

14 Invasive species management can be a victim of its own success when decades of effective

15 control cause memories of past harm to fade and raise questions of whether programs should continue. Economic analysis can be used to assess the efficiency of investing in invasive species control by comparing ecosystem service benefits to program costs, but only if appropriate data exist. We used a case study of water hyacinth (Eichhornia crassipes (Mart.) Solms), a nuisance floating aquatic plant, in Louisiana to demonstrate how comprehensive record-keeping supports economic analysis. Using long-term data sets, we developed empirical and spatio-temporal simulation models of intermediate complexity to project invasive species growth for control and no-control scenarios.

For Louisiana, we estimated that peak plant cover would be $76 \%$ higher without the substantial growth rate suppression ( $84 \%$ reduction) that appeared due primarily to biological control agents. Our economic analysis revealed that combined biological and herbicide control programs, monitored over an unusually long time period (1975-2013), generated a benefit-cost ratio of about 34:1 derived from the relatively modest costs of $\$ 124$ million (\$2013) compared to the $\$ 4.2$ billion ( $\$ 2013$ ) in benefits to anglers, waterfowl hunters, boating-dependent businesses, and water treatment facilities over the 38 -year analysis period. This work adds to the literature by 1) providing evidence of the effectiveness of water hyacinth biological control;2) demonstrating use of parsimonious spatio-temporal models to estimate benefits of invasive species control; and 3) incorporating activity substitution into economic benefit transfer to avoid overstating benefits. Our study suggests that robust and cost-effective economic analysis is enabled by good record keeping and generalizable models that can demonstrate management effectiveness and promote social efficiency of invasive species control. 


\section{Why conduct economic analysis of invasive species?}

38 Robust demonstration of invasive species management program benefits may be crucial to maintaining programs with tight budgets over the long term, particularly if programs are successful at reducing harms, thereby reducing the apparent urgency of action. Yet, such analyses are not possible if agencies do not collect the appropriate data and information. Economic analyses require robust cause-and-effect relationships be established between management actions and environmental changes in order to design control strategies to maximize net benefits (Shackelford et al., 2013) and avoid spending when success rates are low (Wainger et al., 2010). However, the necessary data are often incomplete, largely because conditions prior to control and the effectiveness of control are not fully documented or records are not maintained for long enough.

Control of harmful non-native invasive species is the type of management decision that can benefit from a thorough economic analysis comparing benefits and costs for several reasons. First, efficient spending is needed since there are always more threats to species and ecosystems than resources to confront them (e.g., Wilcove et al., 1998). Second, the ongoing debate about whether we are vilifying invasive species without cause, and thereby wasting resources on their control (Lodge \& Shrader-Frechette, 2003; Shackelford et al., 2013), can often be resolved through economic analyses. While much of the economic literature examines potential optimal control, retrospective analyses of actions are useful because they reveal the harms averted through diligent management and the value of ongoing management or prevention.

\section{What information supports a solid economic analysis?}

For economic evaluations to enable efficient allocation of scarce invasive control resources, values (or indicators of value) must measure outcomes for which people would be willing to pay or otherwise trade off other goods and services. This basic concept, which is fundamental to economic theory, is often obfuscated by studies that quantify benefits of invasive species control in monetary terms that are not measuring economic benefits. In particular, many studies have equated reduced costs of control with benefits (e.g., Sinden \& Griffith, 2007). However, changes in costs of invasive species control do not directly demonstrate that the spending was in the public interest. 
66 The economic measure of benefits, utility, encompasses all tangible and intangible effects on 67 well-being, not only financial effects (Freeman, Herriges \& Kling, 2014). As a result, a wide array of environmental changes will be relevant to cost benefit or cost-effectiveness analysis, if they can be connected to human concerns. For example, many studies have documented peoples' willingness to pay to retain rare species (Richardson \& Loomis, 2009). These nonuse values represent intangible benefits derived from stewardship of the environment. For aquatic species, previously measured benefits include these nonuse values and use values from recreational and commercial fishing, energy supply, water supply, agriculture, industry, tourism, property value support, and flood damages avoided (Lovell, Stone \& Fernandez, 2006).

Even with the best data collection, cost-benefit analysis of proposed invasive species management requires modeling to fill in for unobservable data. A substantial challenge to analyzing benefits of past control is developing the counterfactual or without-action scenario that is needed to understand how management changes outcomes. Data-rich case studies reveal the methods that can be used to dynamically integrate socio-ecological systems and quantify benefits of invasive species control (as described in Olson, 2006). However, sophisticated models are time-consuming or impossible to build for many data-poor case studies and their use is far from routine for evaluating management options.

To ease some of the analytic burdens of measuring economic benefits, many government agencies use economic benefit transfer models for routinely estimating program benefits (Wilson \& Hoehn, 2006). Economic benefit transfer is the process of transferring values that have been empirically estimated for one or more locations to unstudied, or transfer, locations (Johnston et al., 2015). Although this approach is subject to error, the accuracy is generally increased by using studies that are closely matched to the transfer site (Plummer, 2009) or using functional models to adjust values based on the social, economic, and ecological conditions of the site (Johnston \& Wainger, 2015).

Even with benefit transfer, substantial work can be required to apply the technique to quantify how environmental changes impact human concerns (Johnston \& Wainger, 2015; Mazzotta et al., 2015). Modeling complexity can be compounded when temporal and spatial detail is required to accurately assess impacts. For example, the degree of overlap in time between aquatic plant growth and seasonal boat-dependent activities can determine degree of harm (e.g., Adams \& 
96 Lee, 2007). Similarly, a spatial framework may be needed to accurately model effects of

97 proposed management, such as using barriers to prevent range expansion (Sharov, 2004; e.g.,

98 Rahel \& Olden, 2008).

99 An often overlooked component of system response in benefit transfer is the degree to which

100 people adapt to change, which if not considered, can inflate value estimates. For example, Keller

101 et al. (2008) valued the benefits of preventing invasion of rusty crayfish into lakes as the

102 elimination of spending by anglers seeking panfish, since these fish would be extirpated by the

103 invasion. Yet, it is plausible that at least some anglers would switch to alternative lakes or

104 alternative species and enjoy comparable or modestly reduced benefits. Assuming all benefits are

105 lost from an environmental change is common in benefit transfer because data for generalizing

106 how people adapt are poor. Site-specific studies with detailed data can be used to estimate

107 substitution of sites or other adaptations.

108 Although it is always tempting to add model complexity to better capture human-environment

109 interactions and reduce error, complexity also tends to reduce the transferability of methods and

110 findings and increases data requirements. In the analysis that follows, we sought to create

111 parsimonious models to support routine economic analyses of invasive effects (e.g., see Robinet

112 et al., 2012). Yet, we also wanted to include relevant spatial, temporal and behavioral detail to

113 reduce error of estimates. To achieve these goals, our modeling approach combined economic

114 benefit transfer with moderately detailed ecological models. We selected a case study of

115 biological control of an invasive aquatic weed (water hyacinth or Eichhornia crassipes (Mart.)

116 Solms) in Louisiana due to the rich data sources available, but show that even this data-rich case

117 lacks some critical data for measuring outcomes that are primary program goals.

118 Our work adds to the existing literature by 1) providing evidence of the effectiveness of water

119 hyacinth biological control; 2) demonstrating use of spatially and temporally detailed models to

120 estimate ecosystem service benefits of invasive control; and 3) incorporating substitutability of

121 the most valuable ecosystem services to avoid overstating benefits. In addition, we aim to

122 motivate thorough data collection and thereby improve the data landscape for economic studies

123 by highlighting how even small additions to monitoring data can enable economic analysis. 


\section{$124 \quad 3.1$ Case Study}

125 In Louisiana, water hyacinth (Eichhornia crassipes (Mart.) Solms) has been a problem for over a

126 century. Water hyacinth is a widespread invasive floating plant that is often considered one of

127 the world's worst nuisance plants due to its aggressive growth and ability to form large

128 interlocking mats that impede navigation and fishing and impair water quality, among other

129 harms (Howard \& Harley, 1997; Center, 2004; Villamagna \& Murphy, 2010). Water hyacinth

130 was first introduced into the U.S. in New Orleans, Louisiana in 1884 as an ornamental plant

131 (Wunderlich, 1962). Just 15 years later, it had become such an impediment to navigation in the

132 southeastern states that the U.S. Congress authorized the U.S. Army Corps of Engineers

133 (USACE) to clear infestations in navigable waters (Sanders, Theriot \& Perfetti, 1985).

134 A primary concern in Louisiana is that water hyacinth disrupts recreational and commercial

135 boating by limiting access and increasing costs of navigation and maintenance. Small to medium

136 size boats with propeller engines aim to navigate around mats since floating mats clog propellers

137 and water-cooling systems and obscure navigational hazards (South Atlantic Division Field

138 Committee, 1948; Obeid, 1975; Alimi \& Akinyemiju, 1991). In addition, dense infestations

139 block wharves, piers and ramps (Howard \& Harley, 1997). About 80\% of Louisiana recreational

140 boaters surveyed in 2009 moderately or strongly supported "improving aquatic weed control"

141 (Isaacs \& Lavergne, 2010).

142 A wide array of additional harms has also been documented in Louisiana or similar settings.

143 Despite being a detriment to recreational fishing access, a substantial literature documents both

144 harms and benefits to fish communities from water hyacinth with effects apparently dependent

145 on the fish species present and plant density (Villamagna \& Murphy, 2010). Water hyacinth

146 impairs waterfowl habitat by reducing open water area and depleting food sources (Gowanloch,

147 1944). Effects on infrastructure include clogged water intakes of power plants, water treatment

148 plants, and other industries (USAID, 1971; Mailu, 2001; California Department of Parks and

149 Recreation, Division of Boating and Waterways, 2013) and reduced drinking water quality

150 (Mailu, 2001; UNEP Global Environmental Alert Service, 2013). Further, water hyacinth can

151 block streams and drainage canals, reducing their discharge capacity and increasing flooding risk

152 (Gowanloch \& Bajkov, 1948). 


\section{3.1.1 History of water hyacinth control in Louisiana}

154 Mechanical removal and herbicide application were the primary treatment strategies of water

155 hyacinth infestations in Louisiana until the early 1970s, when biological control agents were

156 introduced. Biological control, the intentional introduction of a host-specific organism to

157 suppress a target species, has been used as part of the strategy to manage water hyacinth

158 infestations in many southern states and in a number of countries since the 1970s (Center, 2004).

159 Four insect biological control agents have been introduced in Louisiana, Neochetina eichhorniae

160 and N. bruchi from 1974-1977, Niphograpta albiguttalis from 1979-1981, and Megamelus

161 scutellaris from 2010-2016. N. eichhorniae, or the mottled water hyacinth weevil, was the most

162 successful at establishing and dispersing throughout the state (Coombs, 2004; Grodowitz et al.,

163 2014). Neochetina spp. reduce water hyacinth vigor through larval and adult feeding which

164 reduces production, fertility and spread, and increases susceptibility to herbicides (Goyer \&

165 Stark, 1984; Gettys et al., 2014; Jones et al., 2017).

166 A program coordinated between Louisiana Department of Wildlife and Fisheries (LDWF),

167 USACE, and the US Department of Agriculture (USDA) was successful in dispersing

168 Neochetina spp. within the state from 1975-77 (Manning 1979). Neochetina spp. remain

169 widespread in Louisiana, despite the lack of new releases since the 1980s, although local

170 abundance varies considerably (N. Harms, personal observation, 2017). Variability in weevil

171 populations is likely due to spatially variable habitat conditions including water quality,

172 especially available nutrients, nearby insecticide use and climate. The biological control agent,

173 M. scutellaris, was recently released in Louisiana, but colonization and effectiveness at

174 controlling water hyacinth is unknown. No other biological control agents for water hyacinth

175 were being released as of 2017, and herbicide control is the primary active management tool.

176 Approximately 16,600 ha of water hyacinth control were treated annually from 2000-2013

177 (Alexander Perret, LDWF, pers. comm., January 22, 2015).

\section{$178 \quad 4$ Methods}

179 Using data from multiple government agencies and private businesses, we developed an

180 integrated set of models and analyses to conduct a cost-benefit analysis of invasive water

181 hyacinth control in Louisiana. Of the ecosystem services identified through literature review and

182 interviews with government officials or business owners, four had sufficient data and evidence of 
183 responsiveness to water hyacinth cover for quantitative analysis: 1) recreational fishing from

184 boats, 2) recreational waterfowl hunting from boats, 3) boat-dependent businesses (marinas,

185 tourism), and 4) drinking water supply. Other services were identified that could not be evaluated

186 due to lack of data to quantify harms in the absence of invasive control including: commercial

187 fishing, commercial navigation, flood risk mitigation, hydroelectric production, and nonuse

188 values for species.

189 Ecosystem service benefits were measured as the difference between conditions with and without 190 water hyacinth treatment. Four types of models or analyses made up our integrated suite of tools

191 used to estimate biophysical conditions and benefits (Figure 1): 1) water hyacinth intrinsic

192 growth rate model; 2) water hyacinth spatio-temporal spread model; 3) damage functions relating 193 water hyacinth cover to biophysical changes; and 4) economic benefit transfer analyses.

194 Extensive data were collected to model the with-treatment scenario and historic conditions or

195 data from unmanaged infestations were used to model the counterfactual scenario. Costs were

196 derived from state and federal government records of research and implementation activities for

197 biological control and herbicides. All analyses and models used the time period of 1975-2013 in

198 the state of Louisiana.

\subsection{Intrinsic growth rate model (treatment effectiveness)}

200 Water hyacinth distribution data collected in the spring and fall each year (usually April and

201 November) from 1975 to 2013 (Louisiana Department of Wildlife and Fisheries, 2014) enabled

202 us to model plant growth rate response to biological control. We fit predicted to observed cover

203 data using a logistic growth model that controlled for winter severity by including a variable of

204 days with minimum temperature at or below freezing (Nesslage et al., 2016). The model fit was

205 substantially improved by incorporating a time-varying intrinsic growth rate for water hyacinth

206 such that the growth rate declined through time. Results from this model informed the spatio-

207 temporal spread model, as described below.

\section{$208 \quad 4.2$ Spatio-temporal spread model}

209 Because many benefits and harms of ecosystem changes depend on where and when people are

210 using the ecosystem, we developed a spatially and temporally detailed model of occurrence by

211 adapting an existing parsimonious model, which had been tested on six invasive species,

212 including water hyacinth (Model D, Robinet et al., 2012). The spatio-temporal model included 
213 three submodels: a) habitat suitability model, b) logistic growth model, and c) kernel density

214 function to spread plants across the landscape. The first model was used to parameterize spatial

215 differences in growth and carrying capacity and the latter two models were run in sequence, at

216 each time step to evaluate biomass and spread.

217 We modified the Robinet et al. (2012) model by incorporating a time-varying growth parameter

218 in the logistic growth model (to reflect biological control effects), developing a sparse kernel

219 density function adapted to work over large regions, and fit multiple empirical model parameters

220 to Louisiana data (Appendix A; Supplement S1). For example, we estimated water hyacinth

221 carrying capacity per landscape grid cell by fitting ratios of observed levels of maximum cover

222 (Manning, 1979) to model-generated estimates of habitat suitability (Sutherst, Maywald \&

223 Kriticos, 2007, CLIMEX niche maps, D. Kriticos pers. comm.). We also developed kernel

224 density function parameters by calibrating a simulation model to historic data on water hyacinth

225 coverage by major watershed. Cover data from the period prior to widespread biological control

226 release (1975-1978) provided information on conditions prior to biological control that were

227 used to calibrate the model for the counterfactual scenario.

\section{4.3 Damage functions for ecosystem services}

229 We created a general damage function to relate percent cover to loss of benefits and

230 parameterized the function for each ecosystem service. The damage function generates a

231 proportion (unitless value) that is multiplied by the total potential benefits by location and year,

232 in the absence of water hyacinth. The function documents the degree to which boat travel time

233 increases as a function of percent cover of water hyacinth, up to the point at which a waterway

234 becomes impassible.

235 The damage function was parameterized using findings from landscape ecology since

236 recreational boats navigate around water hyacinth mats in a manner similar to animals navigating

237 a fragmented landscape (Obeid, 1975; Alimi \& Akinyemiju, 1991). Research suggests that the

238 path length that an organism requires to move through a landscape (i.e., connectivity) increases

239 when unsuitable land cover reaches $15-25 \%$ of the landscape (With, Gardner \& Turner, 1997).

240 Further, movement can become impossible when unsuitable cover reaches $70-90 \%$ of the

241 landscape (Mönkkönen \& Reunanen, 1999). Based on these findings, we selected $20 \%$ and $80 \%$

242 as the thresholds to represent the water hyacinth cover that would begin to impede and then 
243 prevent navigation (Figure 2). ${ }^{1}$ The linear segment of the function was drawn to connect these

244 two points and reflected increasing path length as suitable cover (i.e., open water) was lost (after

245 With, Gardner \& Turner, 1997). Selected boat operators were consulted by phone and all

246 concurred that our estimates were realistic.

\subsection{Economic valuation methods}

248 All ecosystem service benefits were estimated through benefit transfer or costs avoided methods

249 that required multiplying a unit value by the number of affected entities (Table 1). In benefit

250 transfer, the final value was estimated as the total consumer surplus, which is a measure of well-

251 being derived from the difference between what a consumer would have been willing to pay to

252 enjoy a service and what was actually paid (Rosenberger \& Loomis, 2001; Freeman, Herriges \&

253 Kling, 2014). Costs avoided were measured as direct expenses avoided.

\section{$254 \quad$ 4.4.1 Benefit transfer methods}

255 Using an existing database (Rosenberger, 2011), we estimated a unit value per recreational user

256 day as the average of 19 studies, selected because they represented freshwater fishing or hunting

257 from boats in southern states. We converted values to 2013 dollars using the consumer price

258 index (Bureau of Labor Statistics (BLS), 2013). We estimated an average user day consumer

259 surplus of $\$ 55.90 /$ day for fishing and $\$ 47.46 /$ day for hunting. The hunting consumer surplus was

260 made a function of existing area suitable for hunting per parish, following methods described in

261 Wainger et al. (2013).

262 Total user days per year were estimated from license sales data (Louisiana Department of

263 Wildlife and Fisheries, 2015) and survey data for fishing and hunting. To estimate freshwater

264 fishing days, two surveys were cross-referenced (Ogunyinka \& Lavergne, 2009; US Fish and

265 Wildlife Service, 2013) and only 20\% of waterfowl hunting days were used from the national

266 survey (US Fish and Wildlife Service, 2013) to represent freshwater activity, as based on a

267 Louisiana survey (Laborde \& Rohwer, 2010). The ratio of permits sold to user days was

268 calculated for the year when both data were available and then applied to convert historic data on

269 licenses to total annual user days for all years.

\footnotetext{
${ }^{1}$ Some types of boats that use air propulsion rather than propeller engines are able to navigate water hyacinth mats without problems. No data were available to quantify the proportion of such boats in use, however, anecdotal reports suggest that these are not in widespread use for fishing, hunting and boat tourism.
} 
270 The affected users by location and time step were determined by comparing spatio-temporal

271 model projections of water hyacinth cover with estimated spatial and temporal usage patterns.

272 Recreational fishing days were distributed to each parish using an angler survey (Ogunyinka \&

273 Lavergne, 2009) and divided into two seasons using monthly crappie fishing effort data, which

274 were the most complete of available data and representative of multiple fisheries (A. Perret pers.

275 comm. and Louisiana Department of Wildlife \& Fisheries, 2013). Based on the survey, we

276 estimated that about $65 \%$ of fishing effort occurred December - April, when biomass of water

277 hyacinth was estimated to be at low winter-spring levels and 35\% occurred the rest of the year

278 when biomass was at or near peak. Hunting days were assigned to parishes based on the

279 percentage of survey respondents that identified a given parish as their favorite (Laborde \&

280 Rohwer, 2010) and distributed evenly across the months in which hunting was permitted.

281 Waterfowl hunting effort was split 50-50 between low and high biomass seasons.

282 The final benefit calculation by recreational service, spatial region and season was the product of

283 user day value and user days, modified by the percent of total benefits per water hyacinth cover,

284 as provided by the damage function (Figure 2 ). The benefits per service per year $\left(V_{y}\right)$ were a

285 weighted sum of the two seasons, as given by:

286

$$
V_{y}=\Sigma_{s=(1,2)} a_{s} \Sigma_{r=(1, \ldots, n)}\left(u d_{y r}\right)\left(b\left(c_{s}\right)\right) \quad \text { (Equation 1) }
$$

287 where $y=$ year; $s=$ season $(1=$ high biomass, $2=$ low biomass $) ; r=$ region $(1, \ldots, \mathrm{n})$ which

288 represents sub-areas of parishes defined by discrete bins of percent cover; $a_{s}=$ proportion of

289 annual recreational activity allocated to season; $u=$ value per user day without water hyacinth;

$290 d_{y r}=$ annual user days per year and region. The function $b\left(c_{s}\right)$ is the damage function that

291 provides the proportion of benefits delivered per water hyacinth cover per season $\left(c_{s}\right)$.

292 Cumulative benefits were the sum of the 38 years of record (1975-2013).

293 In the without control scenario, cover becomes dense and widespread in some areas, resulting in

294 most or all fishing days lost. It is likely that under such extreme conditions some anglers would

295 find alternative recreation activities, rather than lose all recreation benefits. A recent survey of

296 freshwater anglers in Australia suggested that 59\% of anglers would be willing to substitute a

297 different outdoor recreation, if they could not go fishing (Sutton \& Oh, 2015). To account for

298 peoples' willingness to substitute another activity for fishing, we assumed a linear increase in 
299 substitution between $20 \%$ and $80 \%$ water hyacinth cover, up to a maximum of 59\% substitution.

300 We handled substitution differently for hunting by reducing consumer surplus per additional

301 hunting day as huntable area increased. Additional methods are provided in Supplement S2.

\section{$302 \quad$ 4.4.2 Avoided cost methods}

303 Costs avoided were judged appropriate to use because businesses that were affected by water

304 hyacinth were expending resources in management. Marina operators respond to presence of

305 water hyacinth by using boats to mechanically break up mats. The reported costs of control (fuel,

306 labor and equipment) ranged from $\$ 13,000$ to $\$ 23,000$ per marina per year, based on interviews

307 with a small set of operators. Approximately 400 marinas on non-estuarine brackish water

308 (Louisiana Oil Spill Coordinator's Office, 2004) were estimated from GIS analysis to be

309 vulnerable to invasion.

310 Water treatment plant operators, similarly, used boats to mechanically break up water hyacinth

311 mats that clogged intake pipes. The average annual cost of mechanical breakup (including fuel,

312 labor, and equipment) was reported as $\$ 2,300(2013 \$)$ or a range of $\$ 1,100-\$ 3,800$. We

313 identified 77 vulnerable sites using a GIS analysis of surface water intake locations (Louisiana

314 Department of Health and Hospitals, 2006).

315 Avoided costs were scaled to the density of water hyacinth in the vicinity of the marina or

316 treatment plant using the damage function (Figure 2), parameterized for each service

317 (Supplement S3). For both entities, the damage function was scaled by using the average annual

318 cost at $80-100 \%$ cover and assuming spending was 0 at $0-20 \%$ cover. Cover was assessed in the

319 immediate vicinity (grid cell) of the marina or water treatment plant.

$320 \quad 4.5$ Cost of water hyacinth research and control

321 We estimated the total costs of water hyacinth management as the sum of treatment (mechanical,

322 herbicide and biological control), research and program costs for water hyacinth from 1975-

323 2013. Ongoing treatment costs in Louisiana have been borne by the state and the USACE.

324 Research investments were made through the USACE Aquatic Plant Control Research Program

325 (APCRP) on biological, herbicidal and integrated control to manage water hyacinth in the US

326 (1975-1989). US Department of Agriculture, Agricultural Research Service (USDA-ARS)

327 contributed to biological control agent development via efforts such as overseas exploration and

328 host-specificity studies. The USACE Large Scale Operational Management Test (LSOMT) 
329 program (in place 1976-1980) primarily funded release and monitoring of biological control

330 agents in Louisiana (Sanders \& Theriot, 1986). Costs reflected government management

331 activities conducted on public waters and not activities on privately owned lands. Program

332 management costs were included in most data sources but we added a 5\% management cost to

333 federal programs when such costs were not provided. Further information is in supplement S4.

334 Historical (1975-2013) management costs for Louisiana were consolidated from annual reports

335 and spending data from the LDWF, removal of aquatic growth (RAG) programs of the USACE

336 New Orleans District (USACE-MVN) and the USACE Mobile district (USACE-SAM), and the

337 USACE Aquatic Plant Control Research Program (USACE-APCRP). When data were

338 unavailable in some years, we estimated missing values by interpolation, so as not to

339 underestimate spending levels. All values were adjusted for inflation (Bureau of Labor Statistics

340 (BLS), 2013) and reported in 2013 dollars.

341 Three different approaches were used to estimate costs of developing biological control agents

342 for water hyacinth. For each of the two initial Neochetina spp. agents, we apportioned national

343 program research spending (Andres 1977) to Louisiana using the percentage of water hyacinth

344 habitat contained in that state ( $23 \%$ or 2.3 million ha) relative to all US states, including Hawaii

345 (Wainger et al. 2016). Reported costs were not available for development of two other agents,

346 Niphograpta albiguttalis or Megamelus scutellaris, so we conservatively estimated costs

347 associated with N. albiguttalis as the same as Neochetina spp., and estimated M. scutellaris costs

348 using information provided by principal investigators involved with the project (Dr. Phillip

349 Tipping, personal communication).

3505 Results

\section{$351 \quad 5.1 \quad$ Spatio-temporal spread modeling}

352 The results of the spatio-temporal modeling showed substantial differences between the with-

353 and without-control scenarios. The differences in the percentage of water area invaded by water

354 hyacinth were estimated to be $57 \%$ higher in the spring and 76\% higher in fall 2013 (Figure 3)

355 without treatment. The dramatic decline in coverage with control appeared to be supported by an

$35684 \%$ decline in growth rates over the study period (1976-2003) (Nesslage et al., 2016). The 
357 spatial results reflected the north-south gradient in habitat suitability, since abundance was

358 greater in the more suitable (warmer) southern areas (Figure 4).

359 Results strongly suggested that biological control had reduced water hyacinth cover because of

360 the observed decrease in growth rate over time and because we found no statistically significant

361 difference in herbicide use between years with high and low extent of water hyacinth (Exact

362 Wilcoxen Rank Test, Wilcox W=51, $\mathrm{p}=0.14$; high extent defined as $>400,000$ acres statewide),

363 suggesting that herbicide treatment was not responsible for overall historic declines. However,

364 increased efficiency of herbicide treatment may partially explain a lack of correlation between

365 treatment and subsequent declines in cover. We also noted that growth decreased, despite

366 documented increases in average air temperatures over the study period that would tend to

367 increase the growth rate of this tropical plant (Wilson, Holst \& Rees, 2005).

\section{$368 \quad 5.2 \quad$ Economic benefits}

369 The total value of the four ecosystem service benefits over the 38-year analysis period was

370 estimated as $\$ 4.2$ Billion (Table 2). The vast majority of these benefits were from preserving

371 recreational freshwater fishing, which would be substantially impacted during times of peak

372 water hyacinth cover. For 2013, the last year of analysis, the annual benefits were $\$ 195$ Million.

373 The correction for activity substitution had a large effect on values, reducing fishing benefits

374 from $\$ 418 \mathrm{M}$ to $\$ 172 \mathrm{M}$ in year 2013. All reported values are 2013 dollars, unless otherwise

375 specified.

\section{$376 \quad 5.3$ Cost analysis}

377 Costs of research and programmatic expenses of water hyacinth biological control were

378 estimated to total \$29.5 Million across multiple government agencies (Table 3) or \$8.4 Million

379 for Louisiana alone. Among the responsible agencies, a total of approximately $\$ 115 \mathrm{M}$ was spent

380 on herbicide application of water hyacinth between 1975 and 2013. With that cost added, the

381 total spending for Louisiana was $\$ 124 \mathrm{M}$, reflecting the large proportion of herbicide control

382 costs in management spending.

383 Missing data create some uncertainty in these values. Some biological control development costs

384 from the 1970s are lacking due to missing data from large scale rearing and large equipment used 
385 in releasing agents. Herbicide costs were modestly overestimated (5-10\%) because, in some

386 years, program funds were targeted to other plants.

\section{$387 \quad 5.4 \quad$ Cost benefit analysis}

388 When aggregate benefits (Table 2, Cumulative Benefits) were divided by aggregate costs (Table

389 3, Louisiana Cost), the benefit cost (B/C) ratio was 34:1, strongly suggesting that the benefits of

390 water hyacinth control well exceeded the program costs. If we adopt the perspective that $\mathrm{B} / \mathrm{C}$

391 ratios should be evaluated based on the present value at program initiation, all costs and benefits

392 for our case study should be discounted to a present value for 1975 (Hill and Greathead, 2000).

393 When we conducted this analysis, the $\mathrm{B} / \mathrm{C}$ ratio dropped to $6.8: 1$ at a $3 \%$ discount rate or 2.9:1 at

394 a 7\% discount rate. The ratio drops because costs accrue early while substantial benefits accrue

395 many years later. This new B/C ratio based on 1975 present values nonetheless, still suggests

396 that the program is socially efficient, since it more than pays for itself. These analyses show that

397 the $\mathrm{B} / \mathrm{C}$ ratio is sensitive to perspectives built into the analysis and how future users are reflected

398 in the discount rate (See Cropper, 2013).

\section{Discussion}

400 The high $\mathrm{B} / \mathrm{C}$ ratio that we found (34:1) suggests that the investment in developing biological

401 control agents was an efficient use of funds. The aggregate costs of \$124 Million were an order

402 of magnitude smaller than the $\$ 4.2$ Billion in benefits generated in the 38 years of our dataset.

403 This $\mathrm{B} / \mathrm{C}$ ratio is consistent with results from other programs to control water hyacinth or similar

404 aquatic nuisance species, which have ranged globally from 2.5:1 to 124:1 (representing many

405 undiscounted values) (McConnachie et al., 2003; De Groote et al, 2003). Ratios for biological

406 control programs across many types of invasive species have ranged from 1-1000:1 (using

407 discounted values) (Hill \& Greathead, 2000). While many published studies show a substantial

$408 \mathrm{~B} / \mathrm{C}$ ratio, Hill and Greathead (2000) suggested that even if some biocontrol had B/C ratios less

409 than one, when viewed as a portfolio of investments, the high returns to some agents makes the

410 risk of development new agents worthwhile.

411 Although biological control can take time to show effectiveness and does not usually eradicate

412 the target species (Schooler et al. 2004), it has potentially long-lasting, self-propagating, and

413 self-sustaining benefits that offset the initial upfront investment costs. As evidence from this

414 program, releases of agents in Louisiana were discontinued in the 1980's, yet overall suppression 
415 has been maintained (Nesslage et al. 2016). (Recent releases of M. scutellaris in Louisiana have 416 not led to confirmed establishment.) In comparison, management of water hyacinth with

417 herbicide requires continual investment.

418 The regional benefits of control can be hard to perceive given that local populations of water 419 hyacinth remain in many places and may still reach damaging levels. Ongoing herbicide 420 application, or maintenance control, is needed to keep local populations in check, a result that is not uncommon with aquatic weeds that are controlled with biocontrol. However, our evidence, which was developed at the regional scale, supports the idea that water hyacinth would be a substantially greater problem statewide without biological control. These findings reflect conditions from the peak of the damage from water hyacinth that included spatially extensive and tall mats of water hyacinth, that have not been observed in 50 years or more.

Although measured benefits were substantial, our results likely underestimated benefits since we omitted whole categories of values, particularly nonuse values, that can be comparable to use values (e.g., Navrud, 2001; Johnston, Besedin \& Wardwell, 2003) and have been measured for aquatic invasive species cases (McIntosh, Shogren \& Finnoff, 2010). Further, we were not able to include harms suggested by historic information, including increased flooding risk, damage to infrastructure, and disruptions to commercial navigation (as suggested by Thunberg, Pearson \& Milon, 1992). These events were not routinely recorded and predated the tenure of most current emergency managers and harbor masters, which limited our ability to collect information needed to construct models for the counterfactual scenario. In addition, we only included harms to marinas on brackish waters but almost twice as many boat trips take place on freshwater systems, compared to all saltwater systems (Isaacs \& Lavergne, 2010). Further, annual costs to marinas and water treatment facilities were based on relatively modest current infestations and may not be representative of higher infestation levels. Finally, we based our analysis on benefits of agents for only one state, but agents can and are being used in other areas.

440 These benefit omissions did not alter the fact that we found a high benefit-to-cost ratio, which is one way for objectively evaluating optimal level of control (e.g., Leung et al., 2002) and ensuring that benefits of management exceed costs and, therefore, generate net social benefits.

443 Without such analyses, decision makers are left to infer appropriate levels of spending based on

444 incomplete, and possibly biased, information. For example, past problems with biological control 
445 have caused managers to be risk averse to embarking on biological control, even to the extent 446 that past successes might not have been possible under current decision rules (Hinz et al., 2014).

447 Despite its usefulness in this case, cost-benefit analysis must be used with caution since, 448 frequently, many types of environmental benefits cannot be monetized. Costs can appear to 449 exceed benefits due to data or technical limitations of economic analysis, rather than a lack of net 450 benefit. For example, if the ability of invasive species to alter system resilience to stress is poorly 451 understood, the benefits of preventative actions will be underestimated (Shackelford et al., 2013). 452 Non-monetary benefit indicators can be an alternative approach to comparing benefits within a 453 cost-effectiveness framework, when they cannot be monetized (Wainger \& Mazzotta, 2011).

454 Our economic study was enabled by thorough record keeping on patterns of human use of the 455 environment. Recreational fishing and hunting effort was tracked through time in databases of 456 licenses sold and separate surveys evaluated spatial usage patterns and total use. Spatial data on 457 marina and boat launch locations, created in response to the Deepwater Horizon oil spill, enabled 458 the treatment costs avoided analysis.

459 Time series data or widespread spatial coverage that encompass both invasive species cover and 460 human responses can be used to deepen understanding of tradeoffs associated with different 461 intensities of invasive species treatment effort, relative to cover alone. For example, although we 462 were able to use literature to estimate changes in fishing effort as a function of water hyacinth 463 cover, data that encompassed both fishing effort and cover over a range of conditions would have 464 enabled direct empirical modeling of this effect. Further, data on drainage blockages and 465 upstream water hyacinth cover might have allowed other risks to be estimated to improve 466 evaluation of program success.

467 Finally, human adaptations to environmental change need to be incorporated in economic 468 analysis to accurately estimate risk. We used survey evidence to suggest how people might make 469 activity substitutions under extreme conditions of a changed environment. However, future work would be strengthened by explicitly documenting any thresholds or non-linearities of human responses with aquatic plant cover, including willingness to make activity substitutions, such as 472 salt-water fishing. All biophysical and socio-economic changes are ideally measured with before 473 / after and control / impact (BACI) design experiments (Underwood, 1992), which provide the 474 strongest evidence for isolating treatment effects from natural variability. However, since not all 
475 case studies will have thorough studies, results from well-studied locales can be transferred to

476 less studied sites using models and foundational site-specific data.

477 Although the data in Louisiana were among the most comprehensive that we have seen, our 478 analyses have uncertainty due to some data gaps. We could not cleanly separate effects of 479 biological control and herbicides or demonstrate synergies of the two types of treatment (as 480 suggested by Van \& Center, 1994; Center et al., 2002), because presence and density of control 481 agents were unknown and herbicide data were summarized at the annual, statewide scale. Also, 482 further study of species interactions that result from treatment would clarify whether treating one 483 invasive species can facilitate invasion by another (e.g., Santos et al., 2009) and undercut 484 economic gains of treatment.

485 Our study suggested that information does not have to be perfect to conduct economic analyses 486 but that robust analysis is supported by sufficient data and information to demonstrate past 487 management effectiveness or to project future success. Data gaps can be filled with after-the-fact 488 mapping using remote sensing data (Albright, Moorhouse \& McNabb, 2004) and by using 489 modeling to separate causes from effects. We demonstrated the latter approach by using the 490 spring and fall water hyacinth coverage observations and historic weather records to distinguish 491 effects of overwinter mortality from treatment effects, thereby refuting the hypothesis that cold 492 winters that coincided with biological control release were solely responsible for plant declines 493 (Nesslage et al., 2016).

\section{Conclusions}

495 Our cost benefit analysis revealed that water hyacinth control, largely the result of biological

496 control, has generated benefits in Louisiana well in excess of research, development and

497 implementation costs. Using the four ecosystem services with the best data, we estimated a B/C

498 ratio of $34: 1$, due to all forms of control. This high ratio for aquatic plant control is consistent

499 with other literature that safe and effective biological control agents generate net benefits

500 (Lovell, Stone \& Fernandez, 2006) and can dramatically lower management costs of control

501 (Hinz et al., 2014).

502 An additional implication of this work is that sound economic analysis of EGS relies on a

503 substantial amount of data to quantify the many cause-and-effect relationships that link actions to 
504 benefits. Benefit assessments are supported by three fundamental types of observations 1)

505 management effectiveness, 2) ecological outcome changes, and 3) social and economic changes.

506 For natural resource managers, the suggestion is that, if they want to be able to demonstrate

507 economic benefits of programs, they not only track changes in invasive cover (with and without

508 management), but also collect data reflecting potential or observed effects on human activities

509 and use of the environment. For aquatic invasive species, questions to address through data

510 collection include: Does water quality become a problem for aquatic life? Do game animals

511 disappear? Is outdoor recreation participation reduced? Not only must data be collected, but

512 critical data sources must be accessible to researchers over long time periods.

513 We also suggest that costs of economic analyses can be reduced by using generalizable analytic

514 tools, such as the spatio-temporal spread model on which we built. Complex models that require

515 many years of site-specific research to parameterize may not support cost-effective treatment

516 action (Simberloff, 2003). Further, generalizable models may be superior to highly specified

517 models because their projections of future outcomes can be more robust to potential variability

518 (discussed further in Robinet et al., 2012).

519 Our results for water hyacinth in Louisiana are likely to be generalizable to other cases where a

520 safe and effective biological control agent has the potential to suppress an aquatic invasive

521 species that interferes with recreation, boat-dependent businesses and/or water supply. The high

$522 \mathrm{~B} / \mathrm{C}$ ratio that we found suggests that our estimates are robust to the minor cost data omissions

523 that we noted and would only increase if we had been able to add more ecosystem services.

524 Overall, we find that biological control has the potential to deliver a long-term stream of

525 ecosystems services that can justify initial research investments.

\section{Acknowledgements}

527 We are grateful to Kristen Hychka, Elizabeth Price, and Taylor Hollady of UMCES for

528 assistance with analyses and manuscript preparation. We sincerely appreciate the invaluable

529 data, information, and assistance of the Alex Perret, Jack Isaacs, Michael Harden and others,

530 Louisiana Department of Wildlife and Fisheries; Skip Martin, David Fletcher, Glenn Suir and

531 Ned Mitchell, USACE; Ted Center, USDA Agricultural Research Service; Ben Malbrough,

532 Bayou Lafourche Fresh Water District; Ginger Rushing, Assumption Parish Water Plant; Joe

533 Van Marcke, City of Thibodaux; Dirk Barrios, Lafourche Parish Water District No. 1; Michael 
534 Lecompte, Consolidated Waterworks District No. 1 of Terrebonne Parish; David Allemond, 535 McGee's Landing; Coerte Voorhies, The Atchafalaya Experience; Allie Cozad, Red River 536 Waterway Commission; Michael Massimi, Barataria-Terrebonne Estuary Program; Theryn 537 Henkel, Lake Pontchartrain Basin Foundation; Chris Tuckey, U.S. Coast Guard $8^{\text {th }}$ District 538 Waterways Branch; Ted Falgout, Former director of Port Fourchon; and Emily Federer, Port of 539 New Orleans. Thanks also for helpful reviews from Matt Weber, Julie Coetzee and two 540 anonymous reviewers.

5419 References

542 Adams DC., Lee DJ. 2007. Estimating the value of invasive aquatic plant control: A

543 bioeconomic analysis of 13 public lakes in Florida. Journal of agricultural and applied $544 \quad$ economics 39:97-109.

545 Albright TP., Moorhouse TG., McNabb TJ. 2004. The rise and fall of water hyacinth in Lake 546 Victoria and the Kagera River Basin, 1989-2001. Journal of Aquatic Plant Management $42: 73-84$.

548 Alimi T., Akinyemiju OA. 1991. Effects of waterhyacinth on water transportation in Nigeria. Journal of Aquatic Plant Management 28:109-112.

550 Andres LA. 1977. The economics of biological control of weeds. Aquatic Botany 3:111-123. DOI: 10.1016/0304-3770(77)90011-0.

552 Bureau of Labor Statistics (BLS). 2013.CPI Inflation Calculator. Available at 553 http://data.bls.gov/cgi-bin/cpicalc.pl

554 California Department of Parks and Recreation, Division of Boating and Waterways. 2013. Water Hyacinth Control Program and Spongeplant Control Program Aquatic Pesticide Application Plan. https://dbw.parks.ca.gov/pages/28702/files/WHCP\%20SCP\%20Aquatic\%20Pesticide\%2 0Application\%20Plan\%202013.pdf 
559 Center TD. 2004. Water Hyacinth. In: Coombs EM, Clark JK, Piper GL, Cofrancesco AF eds.

560 Biological Control of Invasive Plants in the United States. Edited by Eric M Coombs,

$561 \quad$ Janet K Clark, Gary L Piper, and Alfred F Cofrancesco, Jr. Corvallis, OR: Oregon State

$562 \quad$ University Press.

563 Center TD., Hill MP., Cordo H., Julien MH. 2002. Water hyacinth. In: Van Driesche R, Blossey

Coombs EM., Clark JK., Piper GL., Cofrancesco AF. 2004. Biological Control of Invasive Alfred F Cofrancesco, Jr. Corvallis, OR: Oregon State University Press.

Cropper ML. 2013. How should benefits and costs be discounted in an intergenerational context? RFF Resources 183. http://www.rff.org/research/publications/how-should-benefits-andcosts-be-discounted-intergenerational-context-0

De Groote H., Ajuonu O., Attignon S., Djessou R., Neuenschwander P. 2003. Economic impact of biological control of water hyacinth in Southern Benin. Ecological Economics 45:105117. DOI: $10.1016 / \mathrm{S} 0921-8009(03) 00006-5$.

Freeman AM., Herriges JA., Kling CL. 2014. The Measurement of Environmental and Resource Values: Theory and Methods. New York: RFF Press. reduced by practicing IPM for waterhyacinth (Eichhornia crassipes) control? x/2014-vol-127/FSHS_vol_127/213-216.pdf 
581 Gowanloch JN. 1944. The economic status of the waterhyacinth in Louisiana. Louisiana

$582 \quad$ conservationist 2:3-8.

583 Gowanloch JN., Bajkov AD. 1948. Water Hyacinth Program. In: Louisiana Department of Wild 584 Life and Fisheries: Second Biennial Report 1946-1947. I.D. Chapman (editor). 66-124.

585 Goyer R., Stark J. 1984. The impact of Neochetina eichhnorniae on waterhyacinth in southern $586 \quad$ Louisiana. Journal of Aquatic Plant Management.

587 Grodowitz MJ., Johnson S., Harms NE. 2014. The Use of Megamelus scutellaris Berg in the 588

589 Southern United States as a Biocontrol Agent of Waterhyacinth (Eichhornia crassipes (Mart.)). Defense Technical Information Center. http://www.dtic.mil/dtic/tr/fulltext/u2/a608734.pdf

Hill G., Greathead D. 2000. Chapter 11. Economic evaluation in classical biological control. In: Perrings C, Williamson M, Dalmazzone S eds. The economics of biological invasions. Cheltenham, UK: Edward Elgar, 208-223.

594 Hinz HL., Schwarzländer M., Gassmann A., Bourchier RS. 2014. Successes We May Not Have Had: A Retrospective Analysis of Selected Weed Biological Control Agents in the United States. Invasive Plant Science and Management 7:565-579. DOI: 10.1614/IPSM-D-1300095.1 .

Howard GW., Harley KLS. 1997. How do floating aquatic weeds affect wetland conservation 599 and development? How can these effects be minimised? Wetlands Ecology and Management 5:215-225. DOI: 10.1023/A:1008209207736.

601 Isaacs J., Lavergne D. 2010. The Louisiana Department of Wildlife and Fisheries Survey of 602 Louisiana Recreational Boaters. Louisiana: LDWF. 
603

604

605

606

607

608

609

610

611

612

613

614

615

616

617

618

619

620

621

622

623

624

625

http://www.wlf.louisiana.gov/sites/default/files/pdf/publication/33429-survey-louisianarecreational-boaters/ldwf-boaters-survey-report.pdf

Johnston RJ., Besedin EY., Wardwell RF. 2003. Modeling relationships between use and nonuse values for surface water quality: A meta-analysis. Water Resour. Res. 39:1363. DOI: 10.1029/2003WR002649.

Johnston RJ., Rolfe J., Rosenberger R., Brouwer R. (eds.) 2015. Benefit Transfer of Environmental and Resource Values. New York: Springer.

Johnston RJ., Wainger LA. 2015. Benefit Transfer for Ecosystem Service Valuation: An Introduction to Theory and Methods. Chapter 12 In: Benefit Transfer of Environmental and Resource Values (R. Johnston, J. Rolfe, R. Rosenberger, and R. Brouwer, eds.). Springer.

Jones RW., Hill JM., Coetzee JA., Hill MP. 2017. The contributions of biological control to reduced plant size and biomass of water hyacinth populations. Hydrobiologia:1-12. DOI: 10.1007/s10750-017-3413-y.

Keller RP., Frang K., Lodge DM. 2008. Preventing the Spread of Invasive Species: Economic Benefits of Intervention Guided by Ecological Predictions. Conservation Biology 22:8088. DOI: $10.1111 / \mathrm{j} .1523-1739.2007 .00811 . x$.

Laborde L., Rohwer FC. 2010. 2010 Survey of Louisiana Waterfowl Hunters. Louisiana State University, Delta Waterfowl Foundation. http://www.wlf.louisiana.gov/sites/default/files/pdf/page/32574-researchprojects/ldwffinalreport03-2011a.pdf

Leung B., Lodge DM., Finnoff D., Shogren JF., Lewis MA., Lamberti G. 2002. An ounce of prevention or a pound of cure: bioeconomic risk analysis of invasive species. 

10.1098/rspb.2002.2179.

Lodge DM., Shrader-Frechette K. 2003. Nonindigenous species: ecological explanation, environmental ethics, and public policy. Conservation Biology 17:31-37. Intake Locations.

Louisiana Department of Wildlife \& Fisheries 2013. Louisiana Crappie Fishery Statistics. Inland Fisheries Section.

Louisiana Department of Wildlife and Fisheries 2014. Louisiana Vegetation Cover Data.

Louisiana Department of Wildlife and Fisheries 2015. Recreational License Sales Summary 1972-2013.

Louisiana Oil Spill Coordinator's Office. 2004. Louisiana Marinas and Boat Launches, Geographic NAD83, LOSCO (2004) [marinas_LOSCO_2004]. Available at http://lagic.lsu.edu/data/losco/marinas_losco_2004_faq.html (accessed July 30, 2015).

Lovell SJ., Stone SF., Fernandez L. 2006. The economic impacts of aquatic invasive species: a review of the literature. Agricultural and Resource Economics Review 35:195-208.

Mailu AM. 2001. Preliminary Assessment of the Social, Economic and Environmental Impacts of Water Hyacinth in the Lake Victoria Basin and the Status of Control. In: Biological and Integrated Control of Water Hyacinth, Eichhornia crassipes. Canberra, Australia: Australian Centre for International Agricultural Research,. Aquatic Plant Management 17:39-41. 
648 Mazzotta M., Wainger L., Sifleet S., Petty JT., Rashleigh B. 2015. Benefit transfer with limited

649 data: An application to recreational fishing losses from surface mining. Ecological

650 Economics 119:384-398. DOI: 10.1016/j.ecolecon.2015.09.018.

651 McConnachie AJ., de Wit MP., Hill MP., Byrne MJ. 2003. Economic evaluation of the

652 successful biological control of Azolla filiculoides in South Africa. Biological Control

653 28:25-32. DOI: 10.1016/S1049-9644(03)00056-2.

654 McIntosh CR., Shogren JF., Finnoff DC. 2010. Invasive species and delaying the inevitable:

655 Valuation evidence from a national survey. Ecological Economics 69:632-640. DOI:

$656 \quad$ 10.1016/j.ecolecon.2009.09.014.

657 Mönkkönen M., Reunanen P. 1999. On Critical Thresholds in Landscape Connectivity: A

658 Management Perspective. Oikos 84:302-305. DOI: 10.2307/3546725.

659 Navrud S. 2001. Economic valuation of inland recreational fisheries: empirical studies and their

660 policy use in Norway. Fisheries Management and Ecology 8:369-382. DOI:

661

10.1111/j.1365-2400.2001.00267.x.

662 Nesslage GM., Wainger LA., Harms NE., Cofrancesco AF. 2016. Quantifying the population 663 response of invasive water hyacinth, Eichhornia crassipes. Biological Invasions 18:2107-

664 2115. DOI: $10.1007 / \mathrm{s} 10530-016-1155-9$.

665 Obeid M. (ed.) 1975. Aquatic weeds in the Sudan with special reference to Water Hyacinth.

$666 \quad$ National Council for Research, Agricultural Research Council.

667 Ogunyinka E., Lavergne D. 2009. 2008 Louisiana Recreational Fisherman and Health Advisory

668 Survey Report. http://www.wlf.louisiana.gov/sites/default/files/pdf/publication/32724-

669 2008-louisiana-recreational-fishermen-and-health-advisory-survey-

$670 \quad$ report/survey_report.pdf 
671 Olson LJ. 2006. The economics of terrestrial invasive species: a review of the literature.

$672 \quad$ Agricultural and Resource Economics Review 35:178.

673 Plotnick RE., Gardner RH., O’Neill RV. 1993. Lacunarity indices as measures of landscape texture. Landscape Ecology 8:201-211. DOI: 10.1007/BF00125351.

675 Plummer ML. 2009. Assessing benefit transfer for the valuation of ecosystem services. Frontiers 676 in Ecology and the Environment 7:38-45. DOI: 10.1890/080091.

677 Rahel FJ., Olden JD. 2008. Assessing the Effects of Climate Change on Aquatic Invasive 678 Species. Conservation Biology 22:521-533. DOI: 10.1111/j.1523-1739.2008.00950.x.

679

680

682

683 684 685 686 687 688 689 690 691 692 693
Richardson L., Loomis J. 2009. The total economic value of threatened, endangered and rare species: an updated meta-analysis. Ecological Economics 68:1535-1548.

Robinet C., Kehlenbeck H., Kriticos DJ., Baker RH., Battisti A., Brunel S., Dupin M., Eyre D., Faccoli M., Ilieva Z., Kenis M., Knight J., Reynaud P., Yart A., van der Werf W. 2012. A Suite of Models to Support the Quantitative Assessment of Spread in Pest Risk Analysis. PLOS ONE 7.

Rosenberger RS. 2011.Recreation Use Values Database. Available at http://recvaluation.forestry.oregonstate.edu/database (accessed September 1, 2015).

Rosenberger RS., Loomis JB. 2001. Benefit Transfer of Outdoor Recreation Use Values: A technical document supporting the Forest Service Strategic Plan (2000 revision). Fort Collins, CO: U.S. Department of Agriculture, Forest Service, Rocky Mountain Research Station.

Sanders DR., Theriot EA. 1986. Large-Scale Operations Management Test (LSOMT) of Insects and Pathogens for Control of Waterhyacinth in Louisiana. Volume 2. Results for 19821983. Vicksburg, MS: US Army Engineer Waterways Experiment Station. 
694 Sanders DR., Theriot E., Perfetti P. 1985. Large-Scale Operations Management Test (LSOMT) of 695 Insects and Pathogens for Control of Waterhyacinth in Louisiana; Volume I: Results for 696 1979-1981. Vicksburg, MS.

697 Santos MJ., Khanna S., Hestir EL., Andrew ME., Rajapakse SS., Greenberg JA., Anderson 698 LWJ., Ustin SL. 2009. Use of Hyperspectral Remote Sensing to Evaluate Efficacy of 699 Aquatic Plant Management. Invasive Plant Science and Management 2:216-229. DOI: 700 10.1614/IPSM-08-115.1.

701 702

Schooler, S.S., P.B. McEvoy, and E.M. Coombs. 2004. The ecology of biological control. In: Biological Control of Invasive Plants in the United States. E.M. Coombs, J.K. Clark, G.L. Piper, A.F. Cofrancesco (Eds.). Corvallis: Oregon State University Press. 467 pages.

Shackelford N., Hobbs RJ., Heller NE., Hallett LM., Seastedt TR. 2013. Finding a middleground: The native/non-native debate. Biological Conservation 158:55-62. DOI: 10.1016/j.biocon.2012.08.020.

Sharov AA. 2004. Bioeconomics of Managing the Spread of Exotic Pest Species with Barrier Zones. Risk Analysis 24:879-892. DOI: 10.1111/j.0272-4332.2004.00486.x.

Simberloff D. 2003. How much information on population biology is needed to manage introduced species? Conservation Biology 17:83-92.

Sinden JA., Griffith G. 2007. Combining economic and ecological arguments to value the environmental gains from control of 35 weeds in Australia. Ecological Economics 61:396-408. DOI: 10.1016/j.ecolecon.2006.03.011.

South Atlantic Division Field Committee. 1948. Comprehensive Survey for Removal of Water Hyacinths and Other Marine Vegetable. Atlanta, GA. 
716 Sutherst R., Maywald G., Kriticos DJ. 2007. CLIMEX version 3: User's guide. Hearne Scientific 717 Software Pty Ltd.

718 Sutton SG., Oh C-O. 2015. How Do Recreationists Make Activity Substitution Decisions? A

719 Case of Recreational Fishing. Leisure Sciences 37:332-353. DOI:

720 10.1080/01490400.2015.1016195.

721 Thunberg E., Pearson J C., Milon J. 1992. Residential Flood Control Benefits of Aquatic Plant 722 Control. Journal of Aquatic Plant Management 30:66-70.

723

Underwood AJ. 1992. Beyond BACI: the detection of environmental impacts on populations in 724 the real, but variable, world. Journal of Experimental Marine Biology and Ecology

725 161:145-178. DOI: 10.1016/0022-0981(92)90094-Q.

726

727

728 729 be controlled? http://www.unep.org/pdf/UNEP_GEAS_APRIL_2013.pdf

US Fish and Wildlife Service. 2013. National Survey of Fishing, Hunting, and WildlifeAssociated Recreation (FHWAR) (2011): Louisiana.

USAID. 1971. Economic damage caused by aquatic weeds, preliminary survey. Washington, DC: Office of Science and Technology Agency for-International Development.

USGS National Atlas of the United States. 2014.USGS Small-scale Dataset - 1:1,000,000-Scale Waterbodies and Wetlands of the United States 201403 Shapefile. Available at http://catalog.data.gov/harvest/object/6a447a42-7a9b-420e-b4b1-95a0f307538e/html (accessed August 2, 2015).

Van TK., Center TD. 1994. Effect of Paclobutrazol and Waterhyacinth Weevil (Neochetina eichhorniae) on Plant Growth and Leaf Dynamics of Waterhyacinth (Eichhornia crassipes). Weed Science 42:665-672. DOI: 10.1017/S0043174500077110. 
739 Villamagna AM., Murphy BR. 2010. Ecological and socio-economic impacts of invasive water

740 hyacinth (Eichhornia crassipes): a review. Freshwater Biology 55:282-298. DOI:

741 10.1111/j.1365-2427.2009.02294.x.

742 Wainger LA., King DM., Mack RN., Price EW., Maslin T. 2010. Can the concept of ecosystem services be practically applied to improve natural resource management decisions? Ecological Economics 69:978-987. DOI: 10.1016/j.ecolecon.2009.12.011.

745

746

747

748

749

750

751

752

753

754

755

756

757

758

759

760

761

Wainger L., Mazzotta M. 2011. Realizing the Potential of Ecosystem Services: A Framework for Relating Ecological Changes to Economic Benefits. Environmental Management 48:710733. DOI: $10.1007 / \mathrm{s} 00267-011-9726-0$.

Wainger, L., A. McMurray, N. Harms, A. Cofrancesco. 2016. A framework for assessing economic benefits of invasive aquatic plant management in Louisiana. Information Exchange Bulletin A-16-1, US Army Engineer Research and Development Center, Vicksburg, MS.

Wainger LA., Van Houtven G., Loomis R., Beach R., Deerhake M. 2013. Tradeoffs among ecosystem services, performance certainty, and cost-efficiency in the implementation of the Chesapeake Bay TMDL. Agricultural and Resource Economics Review 42:196-224.

Wilcove DS., Rothstein D., Dubow J., Phillips A., Losos E. 1998. Quantifying threats to imperiled species in the United States. BioScience 48:607-615.

Wilson MA., Hoehn JP. 2006. Valuing environmental goods and services using benefit transfer: The state-of-the art and science. Ecological Economics 60:335-342. DOI: doi: DOI: 10.1016/j.ecolecon.2006.08.015.

Wilson JR., Holst N., Rees M. 2005. Determinants and patterns of population growth in water hyacinth. Aquatic Botany 81:51-67. DOI: 10.1016/j.aquabot.2004.11.002. 
762 With KA., Gardner RH., Turner MG. 1997. Landscape Connectivity and Population

763 Distributions in Heterogeneous Environments. Oikos 78:151-169.

764 Wunderlich WE. 1962. History of water hyacinth control in Louisiana. Hyacinth Control Journal

$765 \quad 1: 14-16$

766

767

768 


\section{Table $\mathbf{1}$ (on next page)}

Ecosystem services analyzed and associated biophysical and benefit metrics 
1 Table 1. Ecosystem services analyzed and associated biophysical and benefit metrics

\begin{tabular}{|c|c|c|c|c|}
\hline Service & $\begin{array}{c}\text { Biophysical } \\
\text { Change (captured } \\
\text { in damage } \\
\text { functions) }\end{array}$ & Unit Value & Affected entities & Benefit Metric \\
\hline $\begin{array}{l}\text { Recreational } \\
\text { Fishing }\end{array}$ & $\begin{array}{l}\text { - Change in boat } \\
\text { access }\end{array}$ & $\begin{array}{l}\text { - Consumer } \\
\text { surplus per } \\
\text { fishing day }\end{array}$ & $\begin{array}{l}\text { - Total user days } \\
\text { per season per } \\
\text { year (low and } \\
\text { high biomass } \\
\text { seasons) }\end{array}$ & $\begin{array}{l}\text { - Consumer } \\
\text { surplus value of } \\
\text { all fishing days } \\
\text { adjusted for } \\
\text { substitution } \\
\text { effects }\end{array}$ \\
\hline $\begin{array}{l}\text { Recreational } \\
\text { Waterfowl } \\
\text { Hunting }\end{array}$ & $\begin{array}{l}\text { - Change in boat } \\
\text { access }\end{array}$ & $\begin{array}{l}\text { - Consumer } \\
\text { surplus per } \\
\text { hunting day }\end{array}$ & $\begin{array}{l}\text { - Total user days } \\
\text { per season per } \\
\text { year (low and } \\
\text { high biomass } \\
\text { seasons) }\end{array}$ & $\begin{array}{l}\text { - Consumer } \\
\text { surplus value of } \\
\text { all hunting days }\end{array}$ \\
\hline $\begin{array}{l}\text { Commercial } \\
\text { Tourism }\end{array}$ & $\begin{array}{l}\text { - Marinas and boat } \\
\text { launches blocked }\end{array}$ & $\begin{array}{l}\text { - Average } \\
\text { response cost } \\
\text { per marina per } \\
\text { year }\end{array}$ & $\begin{array}{l}\text { - Number of } \\
\text { vulnerable } \\
\text { marinas } \\
\text { (brackish water } \\
\text { only; freshwater } \\
\text { unavailable) }\end{array}$ & $\begin{array}{l}\text { - Maintenance } \\
\text { costs avoided } \\
\text { (mechanically } \\
\text { breaking up } \\
\text { mats) }\end{array}$ \\
\hline $\begin{array}{l}\text { Drinking } \\
\text { Water }\end{array}$ & $\begin{array}{l}\text { - Number of water } \\
\text { intakes physically } \\
\text { blocked by water } \\
\text { hyacinth }\end{array}$ & $\begin{array}{l}\text { - Average } \\
\text { response cost } \\
\text { per treatment } \\
\text { plant per year }\end{array}$ & $\begin{array}{l}\text { - Number of } \\
\text { water supply } \\
\text { treatment plants }\end{array}$ & $\begin{array}{l}\text { - Maintenance } \\
\text { costs avoided } \\
\text { (mechanically } \\
\text { breaking up } \\
\text { mats) }\end{array}$ \\
\hline
\end{tabular}

2 
Table 2 (on next page)

Ecosystem Service Benefits results (maximum annual and total over 38 years) 
1 Table 2. Ecosystem service benefits results (maximum annual and total over $\mathbf{3 8}$ years)

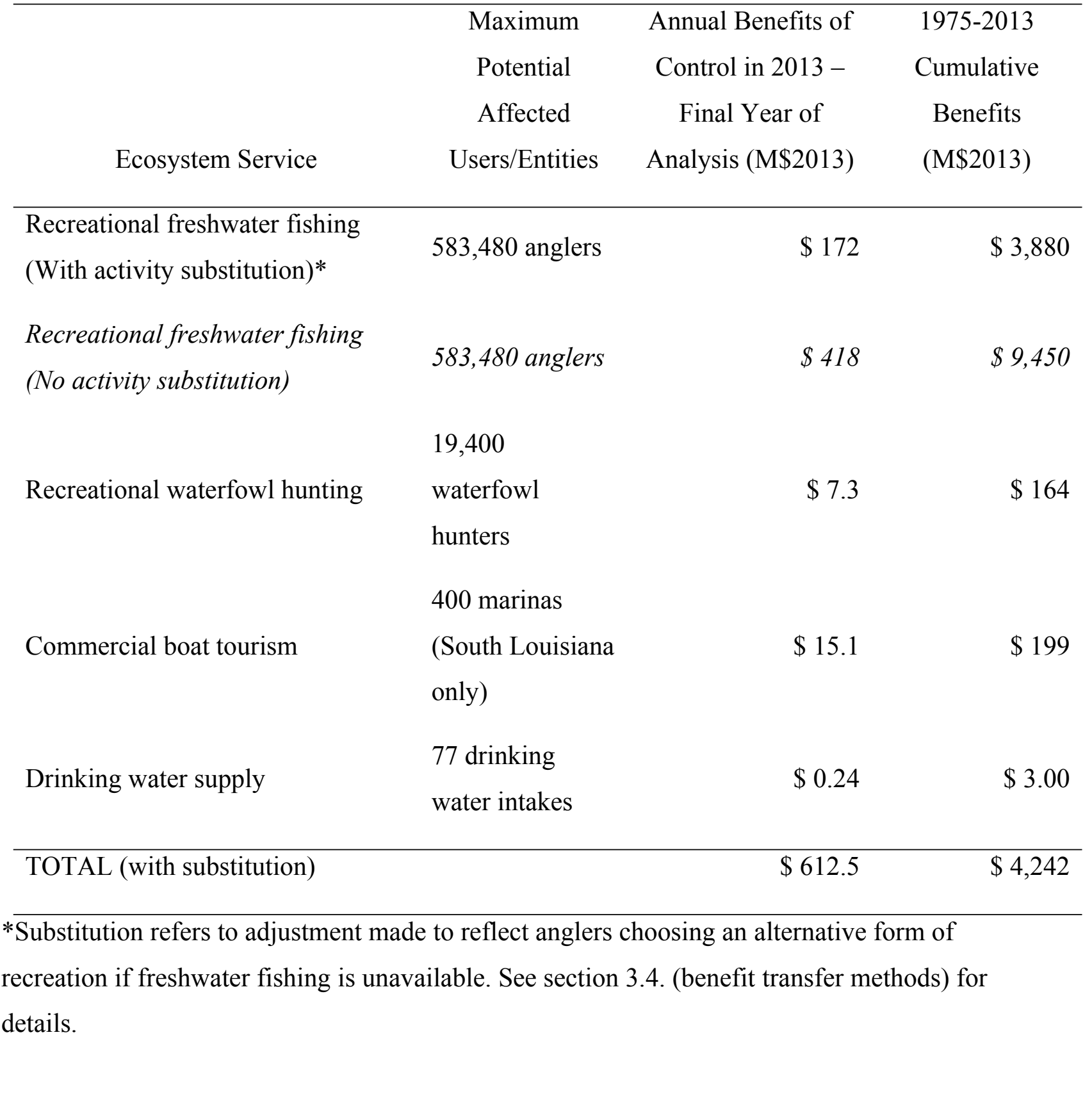




\section{Table 3(on next page)}

Spending on water hyacinth management, research and development from 1975-2013 in Louisiana 
1 Table 3. Spending on water hyacinth management, research and development from 1975-

22013 in Louisiana

$\begin{array}{cc}\text { Total } & \\ \text { Program } & \text { Louisiana Cost } \\ \text { Cost } & (23 \% \text { of research }\end{array}$

Category Organization $\quad(\mathrm{M} \$ 2013) \quad$ costs, $\mathrm{M} \$ 2013)^{*} \quad$ Time period

\begin{tabular}{|c|c|c|c|c|}
\hline Herbicide Research (APCRP) & $\begin{array}{l}\text { USACE- } \\
\text { ERDC }\end{array}$ & $\$ 6.74$ & $\$ 1.55$ & 1976-1989 \\
\hline $\begin{array}{l}\text { Biological Control Research } \\
\text { (APCRP) }\end{array}$ & $\begin{array}{l}\text { USACE- } \\
\text { ERDC }\end{array}$ & $\$ 4.95$ & $\$ 1.14$ & $1975-2014$ \\
\hline $\begin{array}{l}\text { Biological Control } \\
\text { Development }\end{array}$ & USDA-ARS & $\$ 12.76$ & $\$ 2.93$ & \\
\hline $\begin{array}{l}\text { Integrated Control Research } \\
\text { (APCRP) }\end{array}$ & $\begin{array}{l}\text { USACE- } \\
\text { ERDC, MVN }\end{array}$ & $\$ 2.98$ & $\$ 0.69$ & 1976-1989 \\
\hline $\begin{array}{l}\text { Large Scale Operations } \\
\text { Management Test (LSOMT) }\end{array}$ & $\begin{array}{l}\text { USACE- } \\
\text { ERDC, MVN }\end{array}$ & $\$ 2.1$ & $\$ 2.1$ & $1975-1980$ \\
\hline Subtotal for Research & & $\$ 29.53$ & $\$ 8.41$ & $1975-2014$ \\
\hline Herbicide Application & $\begin{array}{l}\text { USACE } \\
\text { LDWF }\end{array}$ & & $\begin{array}{l}\$ 94.6 \\
\$ 20.7\end{array}$ & $\begin{array}{r}1975-2013 \\
1975-2013\end{array}$ \\
\hline
\end{tabular}

\section{Subtotal for Herbicide} application

$\$ 115.3 \quad 1975-2013$

\section{TOTAL}

\$124.36

* See Supplement S4 for further details 
Figure 1

Conceptual diagram of modeling approach

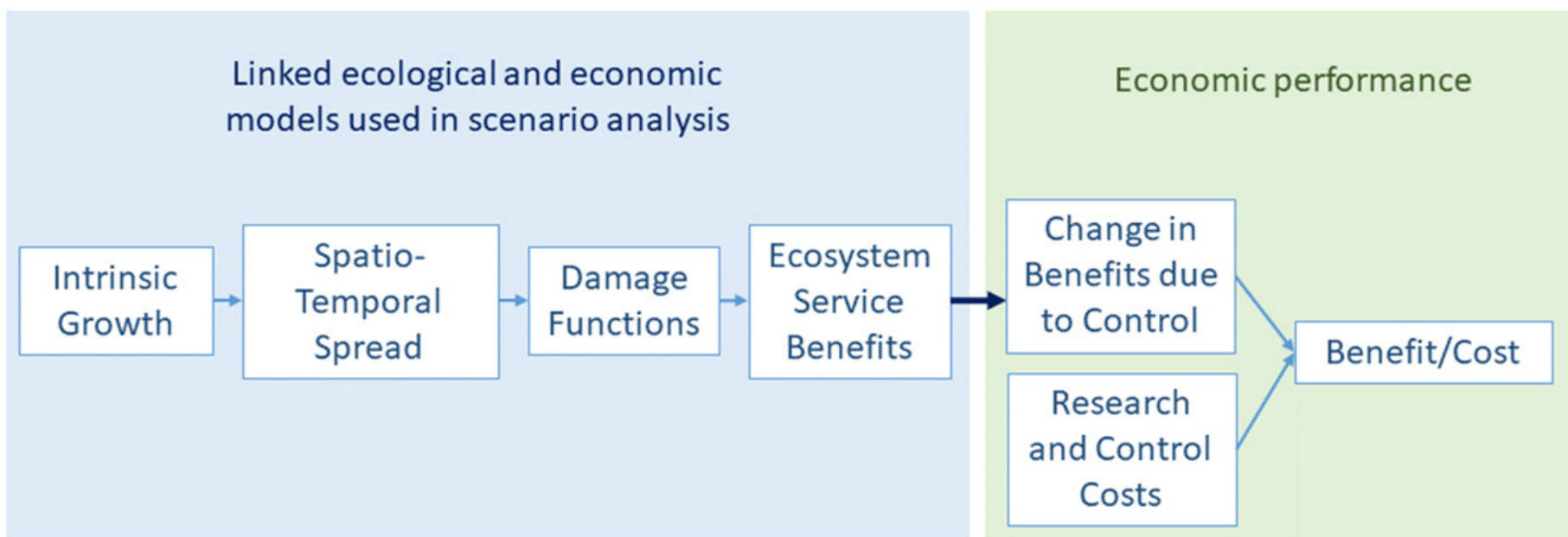


Figure 2 (on next page)

General damage function used to estimate loss of ecosystem service as a function of water hyacinth density 


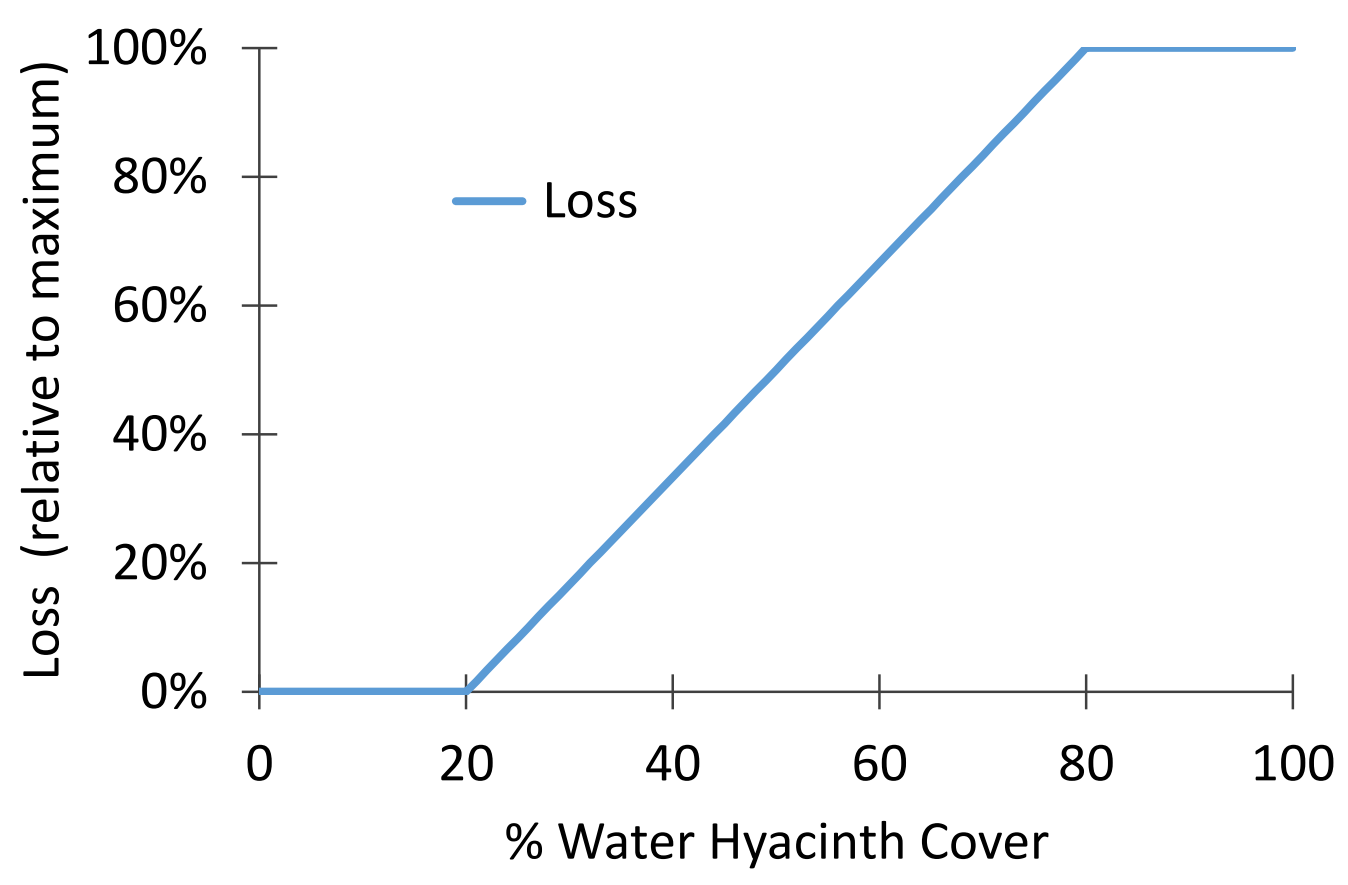




\section{Figure 3 (on next page)}

Simulation of fall water hyacinth density through time, with and without control 


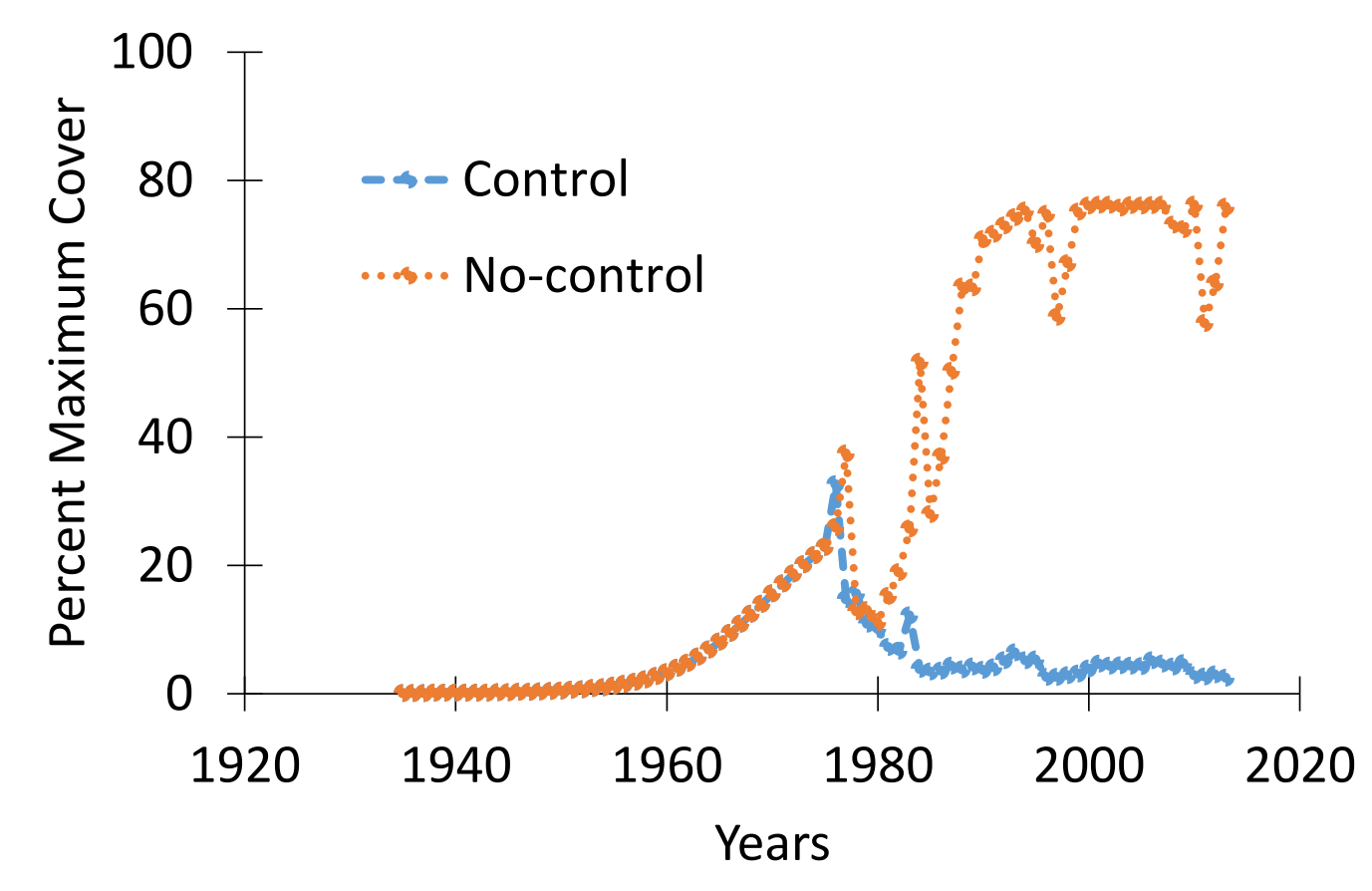


Figure 4

Water hyacinth coverage per grid cell (as \% of water area) for the without and with control scenarios (Fall estimates) 
No Control

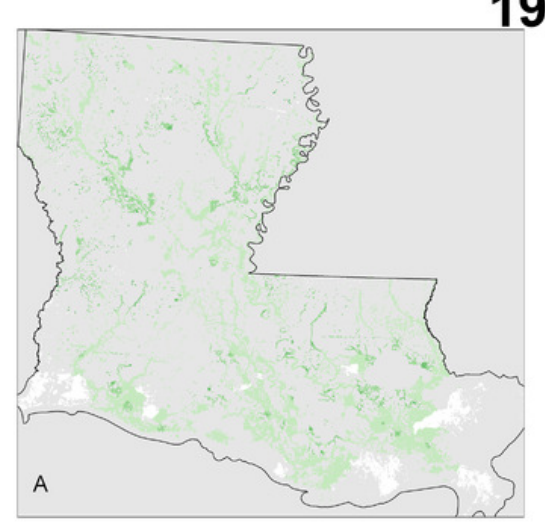

1935

1975

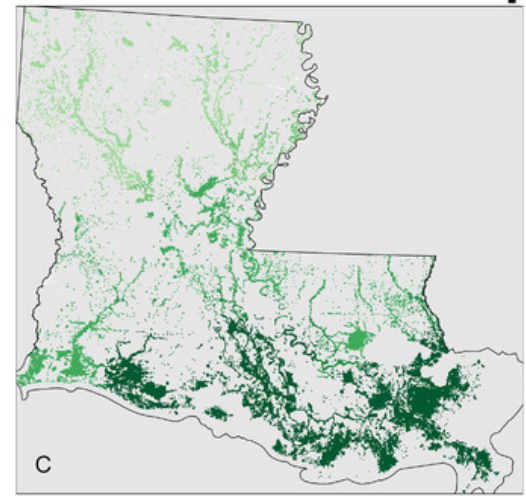

1987
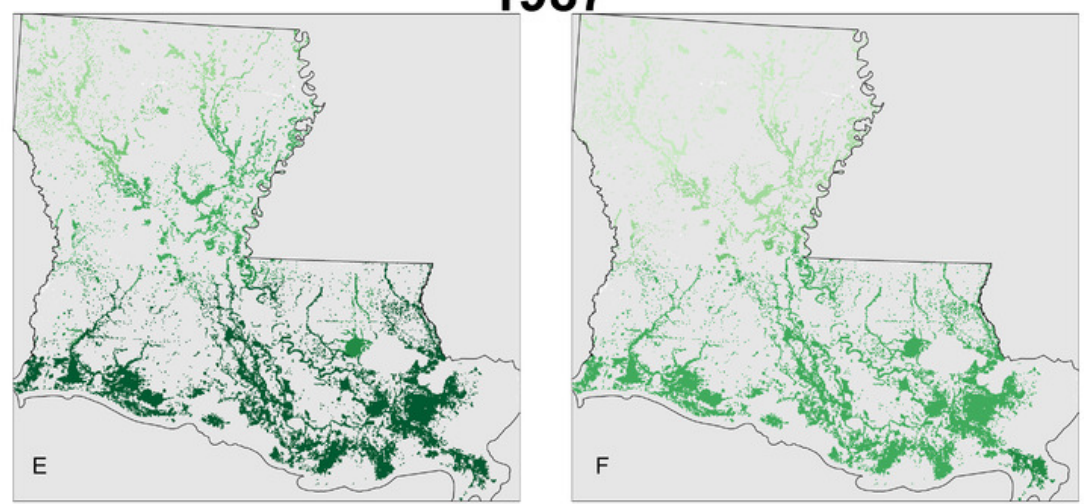

2013
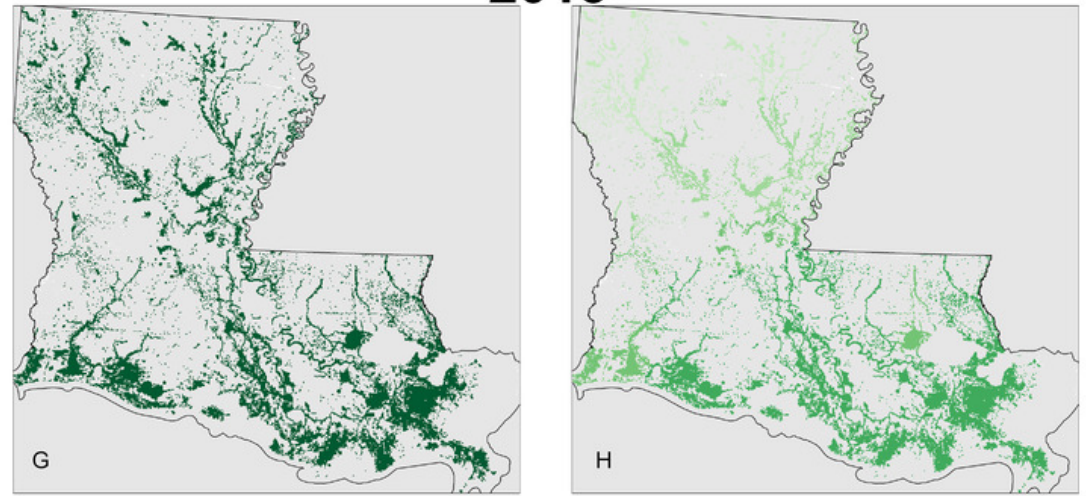

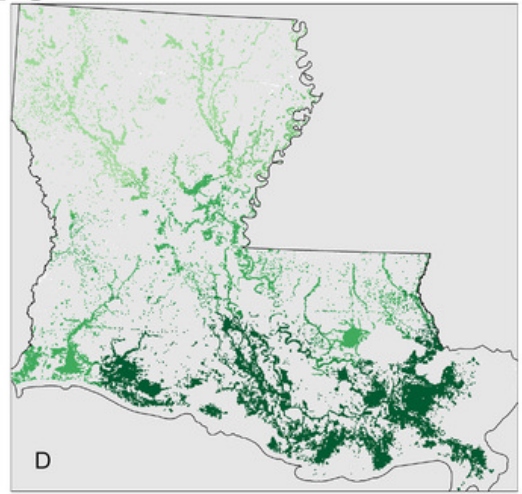

\section{Control}

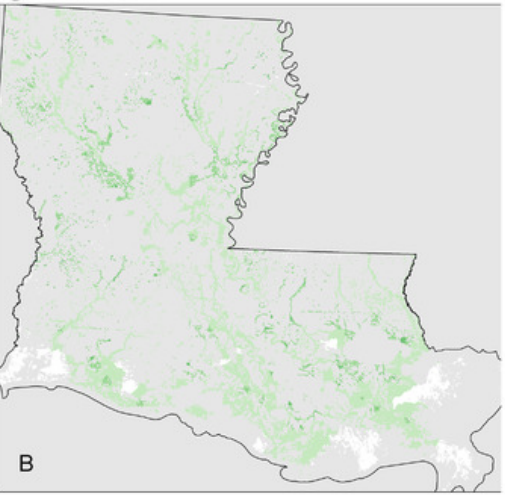

Coverage $(\%)$

$\square$ None

$\square \quad 0-0.1 \%$

$\square \quad 0.2-0.5 \%$

$\square \quad 0.5-1 \%$

$\square \quad 2-10 \%$

$\square \quad 11-20 \%$

- $21-100 \%$ 